\title{
LABOUR MARKET DEVELOPMENTS, NON-STANDARD EMPLOYMENT AND LOW WAGES IN GERMANY
}

\author{
Janine Leschke \\ Copenhagen Business School, \\ Department of Business and Politics \\ jle.dbp@cbs.dk \\ $<$ http://dx.doi.org/10.5565/rev/aiet.28 $>$
}

\section{Resumen}

Con respecto a las novedades introducidas en el mercado de trabajo y sus resultados, a Alemania le está yendo relativamente bien. De hecho, y en contra de la tendencia europea, Alemania ha visto aumentar sus tasas de empleo y el descenso del desempleo durante la crisis económica. Pero desde las reformas desreguladoras de Hartz de principios y mediados de los años 2000, la última década ha sido testigo de la emergencia de formas no convencionales de empleo y el crecimiento del sector de bajos salarios. Uno de los objetivos de las reformas Hartz era aumentar las oportunidades de empleo, entre otros en el sector de bajos salarios, especialmente en el sector servicios. Los trabajadores no estándar y entre ellos aquellos con contratos de duración determinada, los trabajadores de agencias temporales, los trabajadores fijos a tiempo parcial y mini-jobbers son los, comparativamente más afectados por los bajos salarios.

Palabras clave: Empleo atípico, reforma del mercado de trabajo, desregulación, servicios, bajos salarios.

\begin{abstract}
In terms of basic labour market developments and outcomes Germany is faring comparatively well. Indeed, against the European trend, Germany saw employment rates increasing and unemployment decreasing during the economic crisis. But since the deregulatory Hartz reforms of the early and mid-2000s, the last decade saw non-standard forms of employment increasing substantially and the low wage sector surging. One of the aims of the Hartz reforms was to increase employment opportunities, among other in the low wage sector, especially in services. Nonstandard workers and among them fixed-term, temporary agency workers, regular part-time workers and mini-jobbers are disproportionally affected by low wages.
\end{abstract}

Keywords: Atypical employment, reform of labour market, deregulation, services, low wages. 


\title{
Contents
}

\author{
Introduction \\ 1. Recent labour market outcomes in Germany and rise in non-standard employment \\ 2. Erosion of German industrial relations system and growth in non-standard \\ employment \\ 2.1. Mini-jobs - a German phenomenon \\ 2.2. Non-standard employment and growth of the low wage sector \\ 3. Excursion: non-standard employment in the services sector-Germany in a \\ European perspective \\ 4. Conclusions \\ References
}

REFERENCIA NORMALIZADA

Leschke, Janine (2014): "Labour market developments, non-standard employment and low wages in Germany". Anuario IET de Trabajo y Relaciones Laborales, Vol. 2, 67-78. 
LABOUR MARKET

DEVELOPMENTS, NON-

STANDARD EMPLOYMENT

AND LOW WAGES IN

GERMANY

\author{
Janine Leschke
}

\section{Introduction}

Using basic labour market indicators such as unemployment and employment rates Germany has fared comparatively well during the recent economic crisis and is increasingly being upheld as a good example. The recent German labour market success and indeed the turning of the "sick man" into the "Wunderkind" of Europe is often linked back to the socalled Agenda 2020 and the corresponding Hartz reforms of the early 2000. The downsides of this "job wonder" and among them the rise in non-standard employment and particularly mini-jobs and temporary agency work as well as the surging low wage sector and the implications of these developments for social insurance benefits and particularly pensions are less frequently pointed too.

This chapter sets out to demystify the recent German labour market success. It starts with a brief account on labour market developments over the last decade with a specific focus on the economic crisis. It will then address the erosion of the German industrial relations system and the increasing use of forms of non-standard employment. This will be discussed with a focus on mini-jobs as well as the low wage sector which have gained further importance after the implementation of the Hartz reforms in the mid-2000s. In a last section this paper will briefly discuss non-standard and low wage work in Germany in an international perspective with a specific focus on the services sector.

\section{Recent labour market outcomes in Germany and rise in non-standard employment}

In terms of basic labour market developments and outcomes Germany is faring comparatively well. Indeed against the European trend Germany saw employment rates increasing and unemployment decreasing during the economic crisis. Using the latest annual figures of the European labour force survey (LFS) data, unemployment now stands at a long-term low of 5.5\% while the European average rate is $10.5 \%$ (Figure 1). Similarly, with $8.1 \%$ Germany has currently the lowest youth unemployment rate in Europe (EU27 average: 22.9\%) and is uphold widely as a good example with regard to its dual system of vocational training and education. Using the LFS definition of employment where persons are counted as employed if they have worked for at least one hour during the reference week, with $72.8 \%$, and respectively $68.0 \%$, it also stands out in terms of both total and female employment rates. The corresponding EU27 average figures are almost 10 percentage points below these outcomes. Working-time measures such as use of working time accounts and extension of the use of short-time working measures contributed to upholding employment during the economic crisis. 
Figure 1: Labour market outcomes in Germany in international comparison, 2012

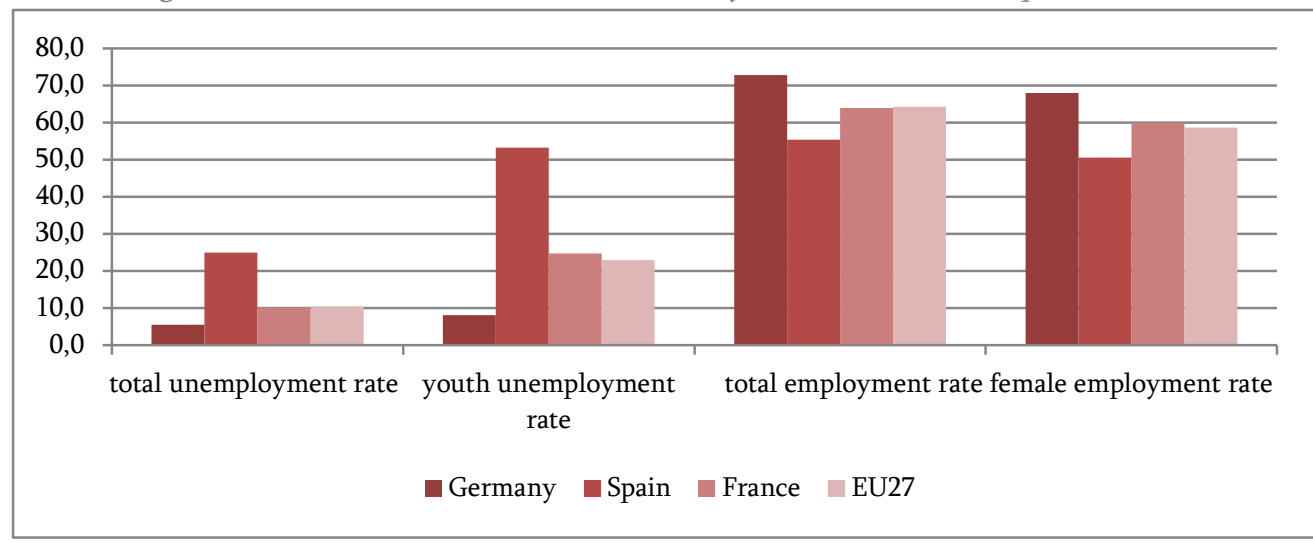

Source: Eurostat Labour Force Survev.

Looking closer at employment figures we see however that there is a strong gender division in terms of working time. As figure 2 illustrates, Germany only slightly lies above the EU27 average in terms of female full-time equivalent employment rates and with $26.7 \%$ it has one of the highest part-time employment rates in Europe - the bulk of which is carried out by women. According to the LFS data, almost half of the German female labour force (45.6\%) works part-time and only in Portugal are average usual weekly part-time hours lower than in Germany. The low average part-time hours in Germany are among others driven by the high share of mini-jobbers (see section 2.1.). With $13.9 \%$ the share of temporary workers (those with a contract of limited duration) is close to the European average; the gender distribution is quite even. The share among youth is above $50 \%$ though in contrast to most other European countries more than $80 \%$ of the young
Temporary agency work is - though small in relative terms - comparatively high (penetration rate of $2 \%$ as compared to $1.6 \%$ on EU average $)^{1}$. There has been a strong upward trend in temporary agency work in Germany since 2003, among other driven by the deregulatory reforms as part of the Hartz packages, with only a brief decrease in the beginning of the economic crisis (Eurociett 2013).

Going beyond quantitative labour market indicators and focussing on job quality using data on EU27 countries, Leschke \& Watt (2013) show that Germany takes at best a mid-way position in terms of the different areas making up job quality (wages, working conditions, involuntary part-time and fixed-term work (inverted), work-life balance and job security, skills and career development and collective interest representation) (see figure 3). Using the overall job

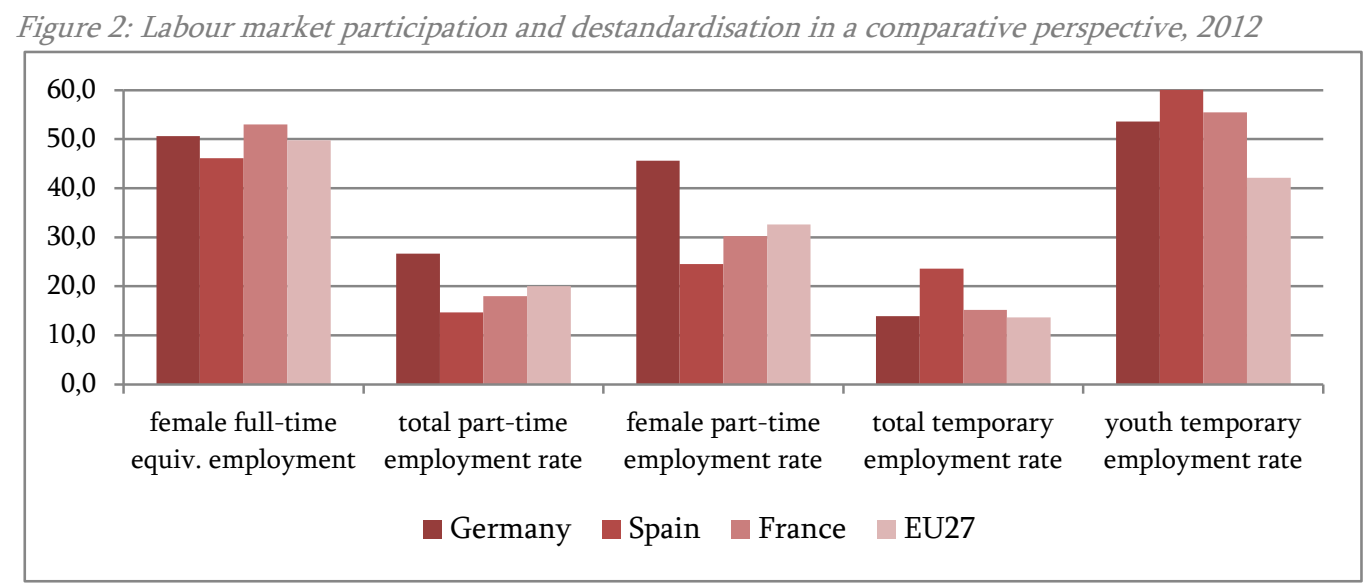

Source: Eurostat Labour Force Survey.

people surveyed stated that they have a temporary contract due to being in education or training.
1 The Spanish and French figures are $0.5 \%$ and 2.2\%, respectively. 
quality index (unweighted average of the six subdimensions) Germany takes place 14, three places below the EU27 average (figure 4). These findings for Germany are also supported by Davoine et al. 2008 and Muñoz de Bustillo et al. 2011.

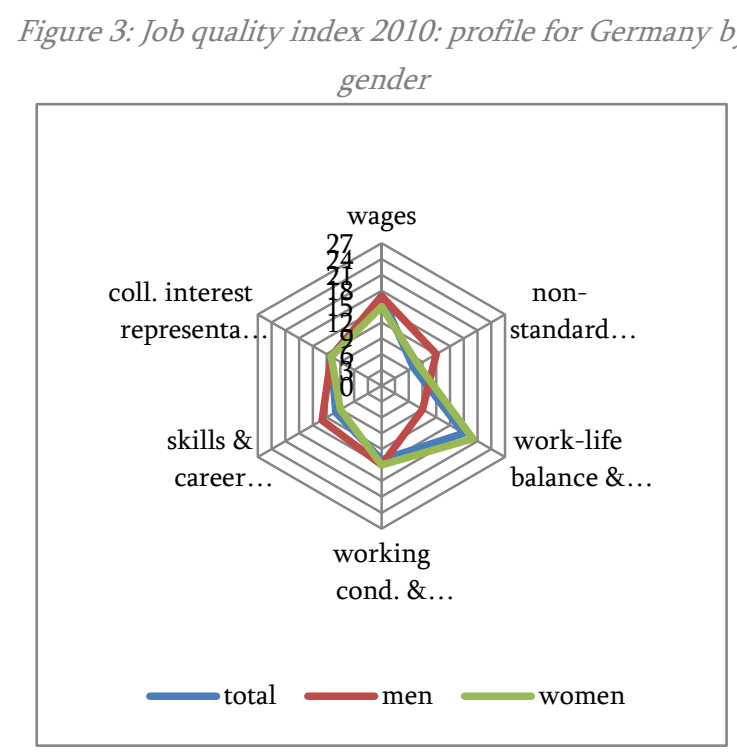

Source: Leschke \& Watt 2013.

Note: Index position: 27: best; 1 : worst

\section{Figure 4: Overall job quality index by gender, 2010}

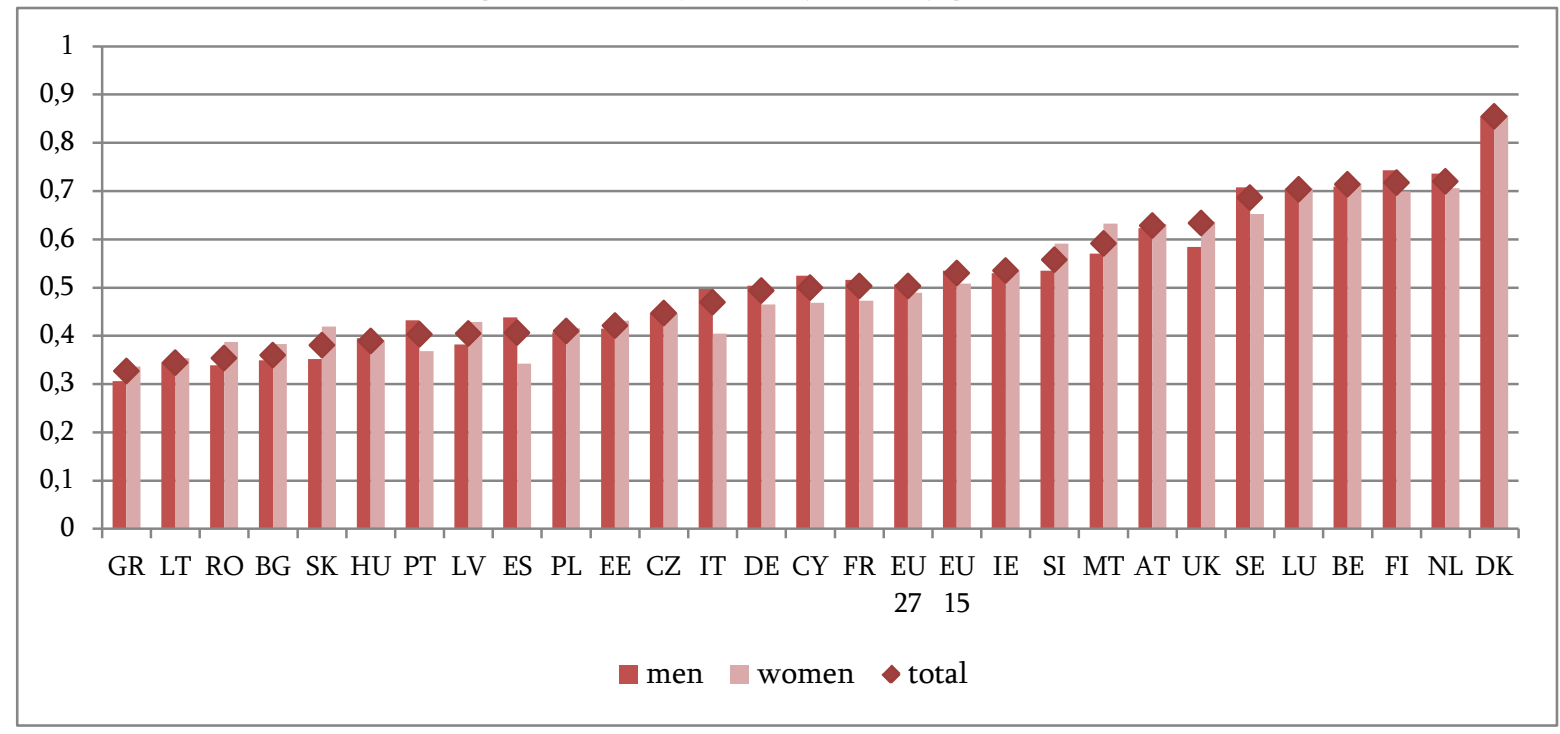

Source: Leschke \& Watt 2013.

\section{Erosion of German industrial} relations system and growth in nonstandard employment

Figure 5 shows trends in labour market participation in Germany over the last two decades. It illustrates that female labour force expansion (in large parts taking place in the services sector) went hand in hand with a decline in terms of total employment subject to social security contributions ${ }^{2}$ and with a rise in both regular part-time employment and so-called mini-jobs. Measured as a share of total employment subject to social security contributions, the level of regular parttime employment was $20 \%$ in 2011 , the one of mini-

${ }^{2}$ Self-employment and mini-jobs are for example not liable to social security contributions. 
jobs (excluding mini-jobs carried out as secondary jobs) was $17.2 \%$. Both were at levels of around $13.5 \%$ in 1999. At the same time, the German labour market saw a boost in low wage employment - with $24 \%$ in 2010 it has one of the largest low wage shares in Europe today. Moreover, the industrial relations system saw serious erosion over the last 20 years. Union density declined from $36 \%$ in the beginning of the 1990s to $18 \%$ in 2011 and collective bargaining coverage fell from around 85\% in 1990 to $61 \%$ in 2011 (ICTWSS data base); collective bargaining coverage is particularly low in East Germany ${ }^{3}$. The next two subsections will look deeper into the phenomenon of mini-jobs and the links between the growth in non-standard employment and the low wage sector.

Figure 5: Labour market participation and destandardisation in Germany over the last 2 decades

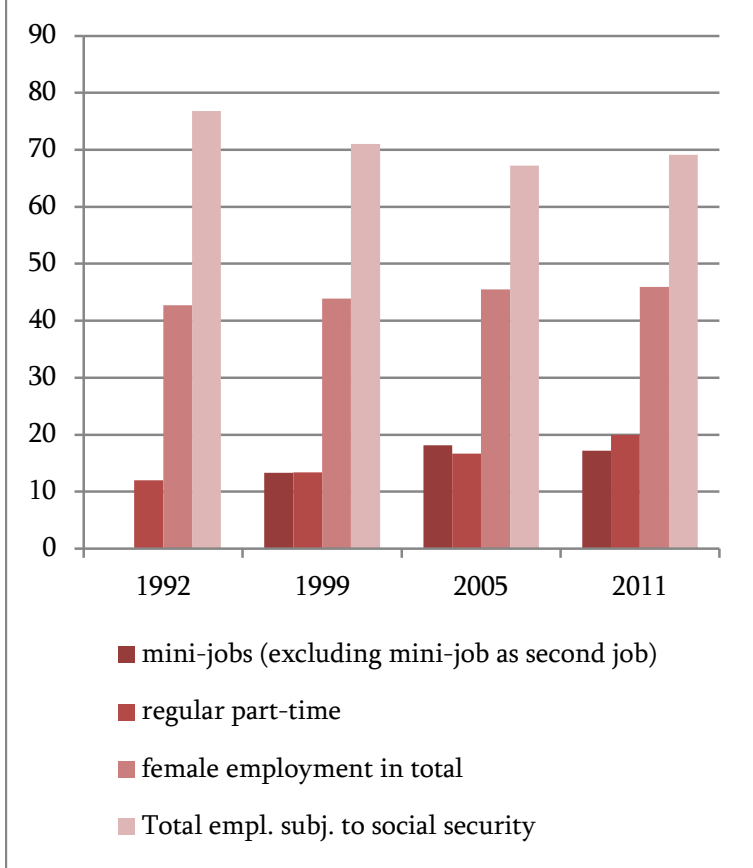

Source: Bundesagentur für Arbeit July 2012.

\subsection{Mini-jobs - a German phenomenon}

The encompassing German labour market reforms, coined Hartz reforms, started in 2002 and comprised a wide range of measures implemented by amending the Social Code through Laws 1 to 4 on modern services in the labour market and phased in over several years. The conversion of the Federal Employment Office into a modern service provider, the improvement of job placement activities and, importantly, the merging of unemployment assistance (formerly paid as a share of the previous wages) and social assistance into a new flat rate means-tested basic allowance (ALGII) at the level of social assistance are the most prominent features. The latter reform increased the pressure on long-term unemployed to take up poorly paid jobs. At the same time a number of deregulatory reforms were carried out that contributed to the growth in non-standard employment. Time-limits with regard to the assignment of temporary agency workers were for example removed which made it possible to replace regular staff with lower paid temporary agency workers and the number of temporary agency workers indeed tripled between 2003 and 2008. Also, incentives for unemployment to start up a business were increased which led to a growth in the share of solo self-employment; solo self-employed are excluded from many social insurance benefits in Germany (Schulze Buschoff \& Protsch 2008).

At the same time marginal employment ("mini-jobs") was further deregulated. The maximum monthly earnings threshold was raised from 325 to 400 Euro and the maximum hour's limit which was previously set at 15 hours was abolished. On top the possibility to carry out a contribution and tax-free mini-job in addition to a regular job was reintroduced.

The main features of mini-jobs are as follows:

- maximum monthly earnings of 450 Euros monthly (since 2013)

- the employer pays a lump-sum of $30 \%$ in taxes and contributions ( $21 \%$ for regular jobs)

- mini-jobs neither generate a "living-wage" nor own social insurance rights in health, care insurance or unemployment insurance and only generate very low pension rights ${ }^{4}$

\footnotetext{
4 Mini-jobbers had the possibility in the past to pay own contributions to retirement insurance to increase their future
} 
While in theory in terms of taxes and contributions mini-jobs are advantageous to employees and are more costly to employers than regular jobs, in reality there is evidence that the additional employers' cost is passed on to the employees by way of paying lower wages (Voss \& Weinkopf 2012). Neither health insurance nor unemployment insurance applies; however, importantly, in practice mini-jobbers often have derived health insurance rights (via their working spouse or the welfare state ${ }^{5}$ ). With regard to labour and collective rights (wages, paid holidays, maternity leave, paid sick leave) no direct discrimination is allowed (TzBfG 21.12.2000). In practice, there is however much evidence that employers do not respect these rights (for the retail sector see Hinz 2012; for the cleaning sector see Riedel 2012).

Figure 6 illustrates the development in mini-jobs since the late 1990s. There was a steady increase over the 2000s and up to 2008. During the crisis the number of people working exclusively on a mini-job was falling whereas the share of people carrying out a mini-job as a side-job was increasing further.
Today there are 7.4 million mini-jobs, counting both exclusive and second jobs.

Women make up two thirds of mini-jobbers and are particularly over-represented in the pool of people holding a mini-job as their only job. This configuration is in line with the male-breadwinner model that the German social insurance and tax system was - and to some degree still is - built on. The most important characteristics of this model are derived social benefits (e.g. health insurance for non-working partners and widower pensions) as well as the tax splitting system which is most favourable for married couples where one partner, usually the wife, is not or only marginal employed and least favourable for couples where both partners have similar earnings.

Every second male but only every fourth female minijobber is under 25 or over 65 years old. The fact that old people take up mini-jobs to boost their pensions is not surprising in view of the comparatively low pension levels of many German pensioners and particularly women (Riedmüller and Willert 2008). The bulk of mini-jobs are exercised in the retail,

Figure 6: Development in mini-jobs (\% total employment subject to social security), 1999-2012

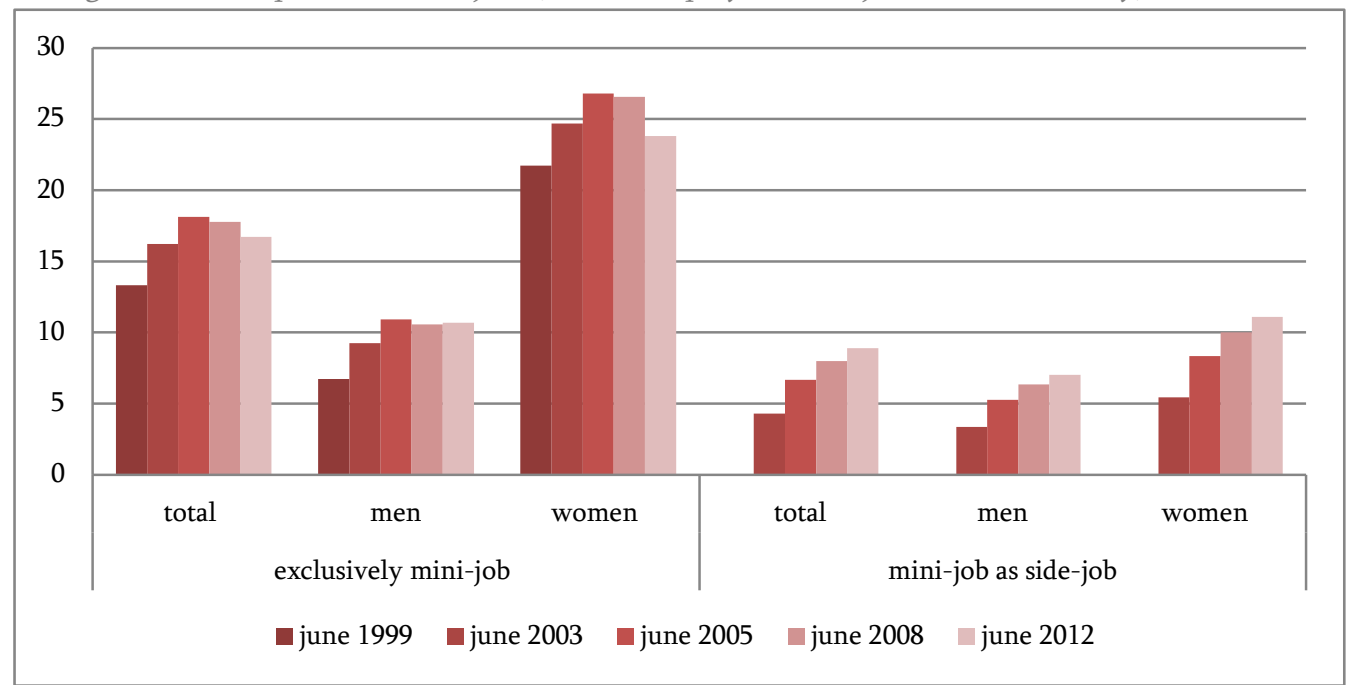

Source: Bundesagentur für Arbeit June 2013.

pensions - this possibility was seldom used. Since 2013, in most cases, retirement insurance contributions are obligatory but with possibilities to ask for deferments. Due to the strong equivalence between wages and retirement benefits, pensions deriving from mini-jobs are minimal.

${ }^{5}$ This applies when workers and their families remain under the social minimum and claim partial unemployment benefits on top of their wages (so-called "Aufstocker"). hospitality and cleaning sector. $45 \%$ of regular female part-time workers and two thirds of mini-jobbers would prefer to work more hours per week: four additional hours for regular part-time workers and 9 additional hours for mini-jobbers on average (Wanger 2011). 


\subsection{Non-standard employment and growth of the low wage sector}

One of the aims of the Hartz reforms was to increase employment opportunities, among other in the low wage (services) sector. This was for example achieved by making it easier for employers and more attractive for employees to use forms of non-standard employment. At the same time the job take-up criteria was made stricter for unemployed and with the introduction of the means-tested basic allowance (ALG II) the pressure on long-term unemployment to take up sub-standard employment and among them mini-jobs increased substantially.

In 2010, almost one in four employees (24\%) in Germany had a low wage (defined as two-thirds of the national median of gross hourly wages) (Rhein 2013 based on EU-SILC data). This is one of the highest rates in Europe; and indeed higher than the UK one. Nonstandard workers are disproportionally affected. The low wage share among full-time workers stands at $18 \%$, whereas the share among part-time workers is $40 \%$, the one for fixed-term workers $51 \%$ (Rhein 2013) and the one for mini-jobbers (main job) is as high as 88\% (Voss \& Weinkopf 2012). Also, the share of nonstandard workers (regular part-time workers, minijobbers, temporary agency workers and workers on fixed-term contracts) in the low wage sector has increased from 49\% in 1995 to $66 \%$ in 2006. (Kalina \& Weinkopf 2008 based on SOEP data). Women are everywhere in Europe more likely than men to have a low wage; the gender difference is particularly large in Germany. Also non-nationals are disproportionally affected. As in most other countries, workers in hotels, restaurants and personal services have higher risks of being on low pay (Bosch 2009).

The principal factors behind the strong increase in the low wage sector since the mid-1990s - between 1995 and 2006 low wage employment grew from 15\% to $22.2 \%$ - are the withdrawal from collective agreements, the rise in outsourcing and posting of workers and - following the Hartz reforms - the dramatic expansion of temporary agency work and mini-jobs (Bosch \& Weinkopf 2009). Collective bargaining coverage has been declining since the mid1990s especially in East Germany. Particularly, many small and medium enterprises have chosen to withdraw from national collective agreements. Another decisive factor is that there is no statutory minimum wage and among the countries without a statutory minimum wage Germany has the lowest coverage rate of collective agreements (European Commission 2009: 82).

Starting with the construction sector, a sector characterised by labour migrants often working on very low wages, since the mid-1990s minimum wages have successively been introduced in a number of industries by way of extension of collective agreements (e.g. construction, postal services, specialist cleaning, nursing services, security, waste management and temporary agency work (Bosch \& Kalina 2010). The level differs from industry to industry leading to an intransparent situation not least for workers. After almost a decade of debates on a statutory minimum wage $^{6}$, the new grand coalition has in its coalition agreement from December 2013 finally decided to phase in a statutory minimum wage of 8.50 Euro from 2015 with possible exceptions until 2017 (CDU, CSU, SPD 2013). Currently, $15.5 \%$ of dependent employees earn less than 8.50 gross. 8.50 Euro is relatively low in a Western European perspective - Ireland, the Netherlands, Belgium, France and Luxembourg all pay hourly minimum wages of more than 9 Euro; the UK minimum wage was 7.63 Euro in 2013 (Schulten 2013). A number of questions with regard to the inclusiveness of the new statutory minimum wage are still open and both politicians and employer organisations have among others been calling for various exceptions including retired persons, students, seasonal workers, long-term unemployment, mini-jobbers and persons working in firms with less than 10 employees (for a critical account see Amlinger et al. 2014).

Low wages (those below the social minimum) can be supplemented by means-tested income support. In practice this means that in 2008, for example, 1.3 million employees received supplements from the basic allowance (ALG II) (Dietz et al. 2009). For the most part, these are part-time workers and mini-jobbers; temporary agency workers are also disproportionally receiving this supplement. However, every fifth person receiving this supplement holds in fact a full-time job (Bosch et al. 2009; DGB 2011). In the absence of a

\footnotetext{
6 There have been vivid debates on a statutory minimum wage since the beginning of the 2000s. Until 2006 there was no consensus between the trade unions on a minimum wage, however since then the German Trade Union Confederation (DGB) has supported a statutory minimum wage of $€ 7.50$ (since May $2010 € 8.50$ ) gross per hour.
} 
statutory minimum wage, firms that pay very low wages are thus subsidised by the state.

\section{Excursion: non-standard employment in the services sector - Germany in a European perspective}

In a European perspective and with a focus on the services sector, Germany performs particularly poorly with regard to the extent and depth ${ }^{7}$ of non-standard employment as well as the gender gap (Leschke 2014, forthcoming $)^{8}$. It is shown that the rise in services employment over the last two decades opened up employment opportunities for women but on the other hand entailed trade-offs with regard to job quality. Female services employment has been shown to be undervalued when it comes to wages and parts of the sector, cleaning being an example in case, are comparatively difficult to organise for trade unions as work places are often small, outsourcing is common and working times are short or irregular. This is manifested in wages that are in many cases substantially lower than in industrial occupations; indeed - as shown above for Germany - in some countries services expansion has been going hand in hand with a thriving low wage sector. In the light of unequal gender distribution of household and care work, a lack in encompassing work-life balance policies and tax splitting policies, women are often obliged to or incited to work part-time hours. Marginal employment is especially problematic as - if exercised exclusively - it will not allow generating an independent income which also has repercussions on social benefits and particularly pensions. Marginal employment is of relatively high importance for women in Germany (mini-jobs), the UK and the Netherlands, and especially in elementary sales and cleaning services.

Particularly the lower strands of services occupations (e.g. personal and protective services and elementary sales and cleaning) are to a high degree characterised by forms of non-standard employment and low wages with women disproportionately affected. Here the

\footnotetext{
${ }^{7}$ This is measured by way of overlaps between forms of nonstandard employment.

${ }^{8}$ This section is based on findings of a forthcoming chapter in an edited volume by Eichhorst \& Marx 2014.
}

degree of public sector employment plays a decisive role as public sector employment usually entails better working conditions among others due to the higher presence and activity of trade unions and higher collective bargaining coverage. The prevalence of nonstandard employment and particularly (low hours) part-time work among lower educated women in the services sector of some countries is also impacted by traditional tax policies such as tax splitting, which tends to be more beneficial at lower earnings, and the marginal cost of child care.

Notwithstanding the general finding that women are in all countries more likely to be non-standard employed and to have low wages or combinations of both and that the problem is considerably more pronounced in occupations that require fewer education, there are important and significant differences across countries. And this is true both in terms of prevalence and depth of non-standard employment in services occupations. The UK, Ireland, Germany and the Netherlands are doing very poorly whereas in particular the Nordic and to some degree also the Central Eastern European countries have been shown to perform better (see figure 7 on country groups).

As regards the latter two country groups it is important to point out that female employment shares are considerably higher in the former than in the latter countries. The Nordic countries thus seemingly manage to combine both services employment of comparatively high quality as well as high female employment rates. This is linked not least to institutions such as encompassing access to child-care for the very young and better functioning industrial relations including high trade union and collective bargaining coverage and the public delivery of services. Those institutions can cushion the evident trade-off between high female employment in the services sector and job quality. This trade-off also adds an explanation to why Southern European countries which also underperform with regard to work-life balance institutions and industrial relations indicators but at the same time have comparatively low female employment rates do better than Continental countries such as Germany and the Netherlands. 
Figure 7: Country groups ${ }^{*}$ with high levels of and high gender gaps in non-standard employment for three occupation groups

\begin{tabular}{|c|c|c|c|c|c|c|}
\hline & & $\begin{array}{l}\text { part-time } \\
\text { (self-def.) }\end{array}$ & $\begin{array}{l}\text { marginal } \\
\text { part-time }\end{array}$ & fixed-term & $\begin{array}{c}\text { solo } \\
\text { self-employment }\end{array}$ & low wages \\
\hline \multirow{2}{*}{$\begin{array}{l}\text { Teaching } \\
\text { professionals }\end{array}$} & level & $\begin{array}{c}\text { Anglo-Saxon \& } \\
\text { Continental }\end{array}$ & Anglo-Saxon & Southern & & Nordic \& Continental \\
\hline & gap & $\begin{array}{l}\text { Anglo-Saxon \& } \\
\text { Continental }\end{array}$ & Anglo-Saxon & Southern & & Continental \\
\hline \multirow{2}{*}{$\begin{array}{l}\text { Personal \& } \\
\text { protective } \\
\text { services }\end{array}$} & level & $\begin{array}{l}\text { Anglo-Saxon \& } \\
\text { Continental }\end{array}$ & $\begin{array}{l}\text { Anglo-Saxon \& } \\
\text { Continental }\end{array}$ & Southern & $\begin{array}{c}\text { Southern \& Central- } \\
\text { Eastern }\end{array}$ & $\begin{array}{c}\text { Anglo-Saxon \& } \\
\text { Continental \& Central- } \\
\text { Eastern }\end{array}$ \\
\hline & gap & $\begin{array}{l}\text { Anglo-Saxon \& } \\
\text { Continental }\end{array}$ & $\begin{array}{l}\text { Anglo-Saxon \& } \\
\text { Continental }\end{array}$ & Southern & & $\begin{array}{c}\text { Anglo-Saxon \& } \\
\text { Continental \& } \\
\text { Southern \& Central- } \\
\text { Eastern }\end{array}$ \\
\hline \multirow{2}{*}{$\begin{array}{l}\text { Elementary } \\
\text { sales \& } \\
\text { cleaning }\end{array}$} & level & $\begin{array}{l}\text { Anglo-Saxon \& } \\
\text { Continental }\end{array}$ & $\begin{array}{l}\text { Anglo-Saxon \& } \\
\text { Continental }\end{array}$ & Southern & Southern & $\begin{array}{l}\text { Anglo-Saxon \& Central } \\
\text { Eastern \& Continental }\end{array}$ \\
\hline & gap & $\begin{array}{l}\text { Anglo-Saxon \& } \\
\text { Continental }\end{array}$ & $\begin{array}{l}\text { Anglo-Saxon \& } \\
\text { Continental }\end{array}$ & Southern & $\begin{array}{c}\text { Southern (in favour of } \\
\text { women) }\end{array}$ & $\begin{array}{c}\text { Anglo-Saxon \& } \\
\text { Continental \& } \\
\text { Southern }\end{array}$ \\
\hline
\end{tabular}

Source: own table based on figures from EU-SILC 2008-2010 data.

* The country groups are as follows: Nordic (Social Democratic) regime (DK, SE, NO, FI), Continental (Corporatist) regime (DE, FR, NL, BE, AT), Anglo-Saxon regime (UK, IE); Southern (Mediterranean) regime (ES, GR, IT, PT); and Central Eastern regime (CZ, HU, PL, SK, SI). Luxembourg, Malta and Cyprus, the Baltic countries as well as Romania and Bulgaria were not included in the analysis.

\section{Conclusions}

This brief account on recent German labour market developments highlights that the currently widely praised success of the German model - and particularly its resilience during the crisis - comes at a cost. Triggered not least by the deregulatory Hartz reforms of the early and mid-2000s, the last decade saw nonstandard forms of employment increasing substantially and the low wage sector surging. Non-standard workers and among them fixed-term, temporary agency workers, regular part-time workers and minijobbers are disproportionally affected by low wages. The share of women but also non-nationals and persons with low education levels in both nonstandard employment and the low wage sector is disproportional. In fact, as the above analysis showed, the expansion in female labour force participation, particularly in the services sector, went hand in hand with a destandardisation of employment forms. This can be explained among others by a lack in work-life balance institutions and particularly encompassing child-care coverage, negative work incentives generated by the traditional tax-splitting system, the lack of a statutory minimum wage as well as the erosion of the industrial relations system and the fact that many of the newly created female jobs are placed in sectors that are traditionally less organised - and indeed more difficult to organise - than the industrial sector. The impacts of the recent initiatives on organising (non-standard) workers in the services sector (Pernicka 2005; Vandaele \& Leschke 2010) as well as the recent grand coalition decision to phase in a statutory minimum wage remain to be seen. 


\section{References}

Amlinger, M., Bispinck, R. and Schulte, R. (2014): Niedriglohnsektor: Jeder Dritte ohne Mindestlohn? Ausnahmen vom geplanten Mindestlohn und ihre Konsequenzen, WSI Report 12.1.2014, Düsseldorf: WSI.

Bundesagentur für Arbeit (June 2013): Statistik der Bundesagentur für Arbeit: Beschäftigungsstatistik, Geringfügig entlohnte Beschäftigung nach ausgewählten Merkmalen, Nürnberg.

Bundesagentur für Arbeit (July 2012): Statistik der Bundesagentur für Arbeit, Arbeitsmarkt in Deutschland - Zeitreihen bis 2011, Nürnberg.

Bosch, G. and Weinkopf, C. (2009): "Working for Little Money: Does Germany really need a minimum wage?". Intereconomics, Vol. 44, Iss. 6, 353-360. < http://dx.doi.org/10.1007/s10272-009-0316-9>

Bosch, G. and Kalina, T. (2010): What role for minimum wages on low-wage work?, in: D. VaughanWhitehead (2010) The Minimum Wage Revisited in the Enlarged EU, Edward Elgar, ILO, pp. 185-212.

Bosch, G. (2009): "Low-wage work in five European countries and the United States". International Labour Review, Vol. 148, No. 4, 337-356. < http://dx.doi.org/10.1111/j.1564-913X.2009.00067.x>

CDU, CSU, SPD (2013): Deutschlands Zukunft gestalten. Koalitionsvertrag zwischen CDU, CSU und SPD für die 18 . Legislaturperiode: http://www.spd.de/linkableblob/112790/data/20131127 _koalitionsvertrag.pdf.

Ciett (2013): The agency work industry around the world, Economic report, 2013 edition (based on figures available in 2011): http://www.eurociett.eu/fileadmin/templates/ciett/docs /Stats/Ciett EC Report 2013 Final web.pdf

Davoine L., Erhel C., Guergoat-Larivière M., (2008): "Monitoring Employment Quality in Europe: European Employment Strategy Indicators and Beyond", International Labour Review, september, No. 147 Issue 2-3, 163-198. < http://dx.doi.org/ 10.1111/j.1564-913X.2008.00030.x>
DGB Bundesvorstand (Februar 2011): "Niedriglohn und Lohndumping im Verleihgewerbe". arbeitsmarktaktuell, No. 2.

Dietz, M., Müller, G. and Trappmann, M. (2009): "Bedarfsgemeinschaften im SGB II: Warum Aufstocker trotz Arbeit bedürftig bleiben”. IAB-Kurzbericht, No. 2/2009.

European Commission (2009): Industrial Relations in Europe 2008, Luxembourg: Office for Official Publications of the European Communities, 2009: http://ec.europa.eu/social/BlobServlet?docId=2535\&lan gId=en

Hinz, L. (2012): "Minijobs im Einzelhandel". WSI Mitteilungen, Schwerpunktheft: Minijobs, Vol. 01/2012, 58-60.

Kalina, T. and Weinkopf, C. (2008): "Konzentriert sich die steigende Niedriglohnbeschäftigung in Deutschland auf atypisch Beschäftigte?". Zeitschrift für ArbeitsmarktForschung - Journal for Labour Market Research, No 4, 447-469.

Lehndorff, S. (2012): "German capitalism and the European crisis: part of the solution or part of the problem?" in: Lehndorff, S. (ed.) A triumph of failed ideas: European models of capitalism in the crisis. Brussels: ETUI.

Leschke, J. and Watt, A. (2014): "Challenges in Constructing a Multi-dimensional European Job Quality Index”. Social Indicators Research, 118, 1-31. < http://dx.doi.org/10.1007/s11205-013-0405-9>

Leschke, J. (2014, forthcoming): "Non-standard employment of women in services occupations: a comparison of European countries, in: Eichhorst, W. and Marx, P. (eds.) Non-standard employment in a comparative perspective, Cheltenham: Edward Elgar.

Muñoz de Bustillo R., Fernández-Macías E., Antón J., Esteve F., (2011): Measuring More than Money: The Social Economics of Job Quality, Cheltenham: Edward Elgar.

Pernicka, S. (2005): “The Evolution of Union Politics for Atypical Employees: A Comparison between German and Austrian Trade Unions in the Private Service Sector". Economic and Industrial Democracy, Vol. 26(2), 205-228. < http://dx.doi.org/10.1177/0143831X05051516> 
Rhein, T. (2013): "Erwerbseinkommen: Deutsche Geringverdiener im europäischen Vergleich". IABKurzbericht, 15/2013.

Riedel, P. (2012): "Minijobs in der Gebäudereinigung". WSI Mitteilungen, Schwerpunktheft: Minijobs, Vol. 65(1), 64-67.

Riedmüller, B. and Willert, M. (2008): "Die Zukunft der Alterssicherung. Analyse und Dokumentation der Datengrundlagen aktueller Rentenpolitik”. Abschlussbericht, Düsseldorf: Hans-Böckler-Stiftung.

Schulten, T. (2013): "WSI-Mindestlohnbericht 2013 Anhaltend schwache Mindestlohnentwicklung in Europa”. WSI-Mitteilungen, 2013/2.

Schulze Buschoff, K. and P. Protsch (2008):“(A-)typical and (in-)secure? Social protection and "non-standard" forms of employment in Europe". International Social Security Review, Vol. 61(4), pp. 51-73. <http://dx.doi.org/10.1111/j.1468-246X.2008.00323.x>

Vandaele, K. and J. Leschke (2010): "Following the 'organising model' of British unions? Organising nonstandard workers in Germany and the Netherlands". Working Paper 2010.02, Brussels: ETUI.

Voss, D. and Weinkopf, C. (2012): "Niedriglohnfalle Minijob". WSI Mitteilungen, Schwerpunktheft: Minijobs, Vol. 65(1), 5-12.

Wanger, S. (2011): "Ungenutzte Potenziale in der Teilzeitarbeit: Viele Frauen würden gerne länger arbeiten”. IAB-Kurzbericht 9/2010, Nürnberg: Institut für Arbeitsmarkt- und Berufsforschung.

Data sources

European Union Statistics on Income and Living Conditions (EU-SILC), micro data, UDB cross-sectional 2010 rev. 2 and 2009 rev. 5 data.

European Union Labour Force Survey (LFS), online data base: http://epp.eurostat.ec.europa.eu/portal/page/portal/emp loyment_unemployment_lfs/introduction

Database on Institutional Characteristics of Trade Unions, Wage Setting, State Intervention and Social Pacts in 34 countries, version 4, April 2013: http://www.uva-aias.net/208
Legislation

TzBfG: Teilzeit- und Befristungsgesetz, 21. December 2000 (BGBl. I S. 1966), most recent change: article 23 (20. December 2011 (BGBl. I S. 2854)). 